\title{
STRATEGY FEATURES OF INFORMATISATION SOCIETY IN THE COUNTRIES OF THE WORLD
}

\author{
Maryna SHUMAIEVA ${ }^{1}$, \\ Taras Shevchenko National University of Kyiv, Ukraine
}

\begin{abstract}
The relevance of research caused by global informatisation and active formation of open information society. Special attention is paid to the unequal distribution of information-communication technologies (ICT) between developed countries and in the society. The purpose of the paper is to analyze different strategies and electronic programs for ICT implementation in different countries. The paper shows that every country has its own way of development of new technologies and transition to the new information epoch. Methodology. Article highlights formation policy of information society for selected countries: USA, Canada, European Union, Japan and Ukraine. The paper analysis strategies and electronic programs for ICT implementation. The comparative analysis and major trends of information society in the world were identified. The historical chronology of adoption of legal acts for development of information society was recreated. Different programs that implement ICT in all spheres of human activity were examined. The legislation is the foundation of all ICT programs that are implemented in the country. Less developed countries should analyze and take into the consideration the experience of countries that have already e-Government. Results. According to the experience of examined countries we can see that the degree of informatisation of the country depends on the direction of the government policy. The formation of the legislative foundation for each country was made approximately in one time but the pace of ICT implementation is quite different. The formation on legislation foundation began nearly in one time in each country but the pace of ICT implementation are quite different. All countries follow global trends and basic principles of information society formation and in the same time include national aspects into the ICT programs. The main aim of ICT program is the distribution of information and communication infrastructure in all areas of human activity, implementation of e-commerce, e-government, etc. In table 1 in the paper there is summarize statistics where is shown several aspects of informatisation: the first year of ICT regulation, the usage of e-government, expert evaluation of dissemination of ICT programs, the percentage of Internet users, expenditure on ICT (percent of GDP). According to the data we can see how government policy can influence on development of ICT in the country.
\end{abstract}

Key words: information society, informatisation policy, information and communication technology.

JEL Classification: B41, C02, L63

\section{Introduction}

The penetration of information technology in public institutions and increasing the number of software became the impetus for creation of new informatisation programs. Each country has its own way of development of new technologies and transition to the new information age. There is a particular level of informatisation in economically developed countries and today's situation and history of such countries shows the way (their national IT programs) that other countries should implement in their economy.

The strategy of entering countries the global information society is undoubtedly based on a comparative analysis of the current state of informatisation, information and telecommunication infrastructure and areas of development.

\section{The politics of informatisation in USA}

Government of the United States has been paying great attention to the establishment of state institutions for the development of telecommunications since $20-30$ years. In those years the Act about Radio was adopted and after that it was replace with Communication Act. In 1978 US National Telecommunications and Information administration was created (NTIA). NTIA regulates the IT-sphere in the United States. Specific NTIA activities are:

- Management of ICT and the definition of spectrum for commercial use;

- administration of grant programs and further deployment and use of broadband and other technologies in America

- Development of policy on Internet economy, including personal information online, copyright protection,

Corresponding author

${ }^{1}$ Department of Economic Cybernetics, Taras Shevchenko National University of Kyiv.

E-mail: marina.netesina@gmail.com 
cyber security and global free flow of information online - Promotion of security and stability of the domain name on the web with participation on behalf of the US government in Internet Corporation for Assigned Names and Numbers (ICANN)

- Conduction of advanced research of IT-area with the Federal government and private sector partners.

A new era in telecommunications regulation in the United States began when President Clinton signed the Telecommunications Act in 1996 (Nicholas Economides, 1998). The main purpose of the act is to demonstrate the commitment of the government to IT sector and the belief that all citizens should have access to modern telecommunications services at reasonable prices provided by the state through the provision of "universal service" even when competition in the market is increasing.

State governments became responsible for the implementation of this strategy. The relationship between state governments was assigned to the Federal Communications Commission (FCC). FCC regulates the domestic and international telecommunication relations in the fifty states and the District of Columbia. In 1972 Congress has passed a law about the creation of the Federal Advisory Committee for objective and affordable advisory services to citizens.

Main responsibilities of FCC are development and implementation of ICT regulation, processing applications for licenses to supply services and other documents, promoting innovative services, making analysis and solving consumer complains, public safety and national security while using ICT, delivering critical information to consumers.

Universal Service Fund (USF) was created to subsidize families with low incomes, education and health infrastructure and other public institutions. The discount varies from 20 to 90 percent and is determined using the matrix. A special collection of recommendations was prepared for state government. This collection "Recommended decisions" contains description of different events how to implement ICT in the society. FCC has developed four programs under the USF for rapid implementation of ICT in the society:

1) The program "Connect America Fund". The program is formally known as the High Cost Support. It is a federal program created to ensure that consumers in rural, remote and far highly expendable areas have access to the modern communication networks, broadband Internet, fixed and mobile services at prices comparable with urban areas.

2) The program "Lifeline". Since 1985 this program provides discounts on telephone service to the category of people with low incomes.

3) The program "E-Rate". The main aim of this program is to connect schools, universities, libraries, medical infrastructure etc.

4) The program "Rural Health Care". The program provides funding for health care workers. People with medical profession should always have access to telecommunications services that are necessary to provide medical care.
US government strategy involves the use of ICTs in the government. Interactive system "Open Meeting” provides an opportunity to ask questions online and provide various suggestions and proposals to the government and receive a reply via e-mail. In 2002 "Electronic Government Act" was approved by both houses of Congress and signed by President of USA.

Speaking about the development of ICT in the United States I should mention about the creation of Internet. Now the whole world uses this network that was first developed for the Armed Forces. For over ten years the Internet was used only by the academic community and in the mid-1990s it was opened to the public.

\section{The politics of informatisation in Canada}

Nowadays Canada is a world leader in information. Canada has one of the highest rates of broadband penetration among OECD (Organization for Economic Co-operation and Development). Government policy promotes the spread of broadband especially in rural and regional areas. As a result $98 \%$ of Canadians have access to broadband services. In 1993 the Telecommunications Act was passed. This act served to strengthen the legal regime for ICT which has previously been spread among a number of laws. The most important thing is that the law formulated the objectives of the parliament policy about the development of the ICT sector in Canada. It should be noted that the act was passed earlier than in the US. The US government took the Canadian way.

In the 90s Information Technology Association of Canada was created. It is the voice of the information technology industry in Canada. The Association represents a diverse ICT community that covers telecommunications and Internet services, consulting, ICT services, hardware, microelectronics, software and electronic content. Community ITAC contains more than 572 thousand jobs, 140.5 billion dollars revenue, 6.0 billion dollars in $\mathrm{R} \& \mathrm{D}$ investment, 31.4 billion dollars exports and 11.4 billion dollars capital costs. All this is an annual contribution of ICT to the economy of Canada. There are six priority areas for ICT development in Canada: the global competitive ability of the knowledge economy in Canada, the use of ICT, procurement in the public sector, e-health, intelligent regulation and talents.

Simultaneously with the adoption of the Telecommunication Act the government formed Information Highway Advisory Council (IHAC). The goal of IHAC is to ensure the development of Canada's strategy to connect to the information superhighway.

Government has developed a comprehensive program "Connecting Canadians" (Jake Enwright, 2014). The program consists of several blocks each of which includes a system of programs focusing on specific sector of informatisation of the country. One of the units includes programs Canada-online and Connecting Rural Canadians. The aim of these programs is to provide Internet access to educational, medical, scientific and research institutions by providing subsidies and preferential terms to the access 
of the above institutions. Also a special system was created to update obsolete equipment and to provide institutions with upgraded informational devices.

Another unit of the program "Connecting Canadians" is focused on e-commerce. This unit is called "Canadian Electronic Commerce Strategy”. It contains mainly series of laws to establish protection for consumers and sellers, to make standard-setting for electronic correspondence. The third unit contains applications for e-government development. The main idea of this unit is to create a functioning e-government when all government services can be done online.

Recently the Government of Canada presented the new program “Digital Canada 150”. It is Canada's Digital Future plan which the country plans to reach its 150th anniversary. The plan consists of five main points (James Moore, 2015): connection of Canadians, protecting of Canadians, economic opportunities for Canadians, e-government, Canadian content. Government policy is focused on increasing demand for IT tools, creating and attracting qualified foreign specialists using the Start-Up Visa, increasing production software, expansion of information and telecommunication infrastructure.

\section{The politics of informatisation in EU}

The European Union develops and implements a system of programs to bring the economy of the EU to the forefront in the world, to make better working conditions, to increase the level of social well-being and to make a competitive and dynamic society.

Beginning from 1994 the European Community puts on consideration the building of the Information Society as one of the priority tasks. The foundation of legislation of ICT in the EU became two directives of the European Parliament: "About the processing of personal data and the protection of private interests in the field of telecommunications" in 1997 and "About a number of legal aspects of electronic commerce in the internal market" in 1998. Europe Action Plan was launched by the President of the European Commission Romano Prodi in December 1999. This plans gave a new direction in the various EU programs such as IDA (electronic data interchange program between administrations) to ensure benefits for citizens and businesses.

In March 2000 at the Lisbon Summit new objectives were defined for the European Union for the next decade. The result of the summit became the program "e-Europe 2002" (e-Europe Action Plan). The objectives of the program can be grouped into three parts: cheap, fast and secure Internet, investment in people and their skills and knowledge, promoting the use of Internet.

By 2005 the candidate countries for EU accession had to implement program of e-government. Also attention should be paid to the program "IDA". The program aims to promote the development and operation of transEuropean networks for the exchange of data between the administrations of the Member States and Community institutions. The first phase of the program, which began in 1995, contributed the creation of large telematics networks in the areas of employment, health, agriculture, statistics and competition. The second phase of the program (IDA II) was launched in 1999 with the adoption of the two present decisions. The program was redirected toward interaction with the market in order to improve the delivery of online services (e-government) to the European businesses and citizens.

The "e-Europe 2005" was a logical continuation of a successful plan "e-Europe 2002" with more practical goals and funding sources. The main objectives of the program "e-Europe 2005" was the creation of modern public services to interact with individuals in real time, electronic government, electronic education, e-health, e dynamic business environment, secure information infrastructure, benchmarking and distribution of broadband access at competitive prices.

One of the sources of the financial implementation of this program is the budget of the 6th EU Framework Program for Research and Technological Development 2003-2006. So-called "Framework Programs" (FP) are the main organizational structures that coordinate research and technological development in the EU.

Eight framework programs were already introduced. The budget of FP every next program increases form 3.5 billion euro to 53.22 billion euro (for FP 7). Nowadays the eighth framework program is going. The name is "Horizon 2020". The budget of the program is allocated 80 billion euro. The slogan of the program is to turn the European Union on the Innovation Union.

Following the "E-Europe 2002" and "E-Europe 2005" the new program started "Strategy i2010". Today we see the implementation of the program "e-Europe 2020". Digital Day procedure (Digital Agenda, DA) is one of the seven main missions of the program "E-Europe 2020". DA proposes the following tasks to do for better exploitation of ICT potential:

1) Creation of a single digital market across the EU

2) Increasing interaction and standards, interoperability of devices, applications, data warehousing and creation of appropriate rules for intellectual property rights

3) Strengthen policies to combat cybercrime, distribution of child pornography and violation of privacy

4) Providing high-speed Internet at competitive prices. The EU should create next-generation networks (NGAs) broadband infrastructure

5) Promoting digital literacy for various segments of the population, the involvement of young ICT specialists and retraining of the unemployed.

\section{The politics of informatisation in Japan}

The most rapid development of informatisation in the world is in Asian countries such as South Korea, Taiwan, Hong Kong, Japan and Singapore. The Asian strategy of informatisation of society will be analyzed on the basis of Japan. 
In light of the urgency of adaptation to rapid and drastic changes in the world caused by the use of ICT the strategic IT headquarters were created in January 2001. After that the program "E-Japan" was adopted to establishment formation of advanced information and telecommunications network. In March 2001 the program was complemented with the documents "e-Japan: program policy priorities".

The program was designed for 5 years with fairly persistent goals: "Japan must take revolutionary yet realistic actions promptly in order to create a "knowledgeemergent society" where everyone can actively utilize IT and fully enjoy its benefits. We will strive to establish an environment where the private sector, based on market forces, can exert its full potential and make Japan the world's most advanced IT nation within five years."

In June 2001 the program "E-Japan 2002" was adopted. Already in 2002 all the Japanese schools were connected to the Internet and computer science became mandatory subjects. In 2003 the new document "e-Japan strategy 2" was approved. Almost every year the country moved with big steps forward creating new programs, introducing new laws and implementing IT to every element of life.

In the above document the following sectors of implementation of IT were mentioned: health services, nutrition services, a system of communication with immediate response in emergency, a system of remote video communication for seniors, financing of small and medium enterprises for rapid business growth and economy increase, the use of IT to create an internationally competitive human resources, creation of electronic information exchange for people seeking employment and landlord, providing open access to administrative information, web pages of all administrations and public relations channel (E-Japan Strategy II, 2003).

The program "E-Japan" every year was updated and enriched. The program contributed a sizeable reduction of tariffs on all kinds of communication. "E-Japan" has been changed a number of laws including the main "About telecommunications". One of the interesting laws is the ability to save a mobile phone number while changing one mobile operator to another.

In August of 2003 "Basic Resident Register Network System" begin to work. It is automated electronic the system of population registration. And in January 2004 electronic systems for tax payment and government feed were implemented. The "electronic government" is actively developing in Japan.

In 2013 Japan government presented the new document "Declaration of becoming the most advanced IT nation in the world".

\section{The politics of informatisation in Ukraine}

Since the middle of last century Ukraine has contributed the development of computer technology and the latest technology. In 1925 O.M. Schukaryevym invented the idea of mechanization of formal logical operations and built "mechanical thinking machine”. In 1948 S. Lebedev explained the structure and principles of digital computers. In the 1950-1980 V. Glushkov formulated the basic principles of computer science scientist. In 1997 the IEEE Computer Society awarded Glushkov V. and S. Lebedev with the medal "Pioneer of computer technology". An excursion into history has shown us that Ukraine must be among the leaders who are making the foundation of an information society. But unfortunately we are still far from ideal.

A powerful impetus to the development of Ukrainian information society became the creation of regulatory legislation. The basic crucial laws were passed: "About electronic documents" (2003), "About electronic digital signature" (2003), "About telecommunications" (2004), "About basic principles of Information Society in Ukraine for 2007-2015" (2007), the resolution of the Cabinet of Ministers of Ukraine "About approval of the National System of Indicators of the Information Society” (2012), the act of the Ministry of Education and Science of Ukraine "About the approval of methodology for formation of indicators of the Information Society" (2012).

In 2003 Ukraine joined the declaration of principles and plan of action for the development of the information society that was adopted at the World Summit in Geneva. The logical step forward this direction was the signing the decree by the President of Ukraine "About urgent tasks in implementing new information technologies" on the 20th of October, 2005.

At the same time the above listed documents are not ideal, they need to be harmonized and to be brought under the EU standards.

The first and only time assessment of Ukraine's readiness for e-Government was held in 2002. Its results have become the basis of the information and analytical component of the National Program "e-Ukraine". Due to objective and subjective reasons the implementation of this program didn't take place. A lot of time passed, the ICT sector significantly changed both information technology and the level of information users' culture.

In 2001 the program "Innovation trampling" was initiated. The role of this program is to facilitate the process of sustainable national development and poverty reduction through the use of ICT. Ukraine also takes part in international telecommunication projects ITUR (Italy Turkey - Ukraine-Russia), TAE (Tran-Asia-Europe), and other programs.

In 2013 Ukraine National Center for e-governance SE "Derzhinformresurs" evaluated the electronic readiness of Ukraine commissioned by the State Agency for Science, Innovation and Informatisation of Ukraine. According to the results of the analysis now Ukraine has the following development stage: the installation of computer software is done and access to the Internet is connected, almost all institutions have a web page. However, business processes in these institutions not related to e-government but almost all institutions are ready to implement it. Institutions do not perform the necessary functions of administrative services to citizens and businesses and do not have a sufficient level of electronic interaction even at 
the domestic level. So virtually no elements of electronic democracy are nearly absent.

The program of President of Ukraine "Reform Strategy 2020 " was recently published. One of reforms in this program is concerning electronic governance. E-government program will be implemented in accordance with the vector of security and development of the information society is according to the vector of pride for Ukraine. According to UNIAN (Ukrainian Independent Information Agency) Ukrainian government plans by 2017 to pass the law about the single electronic interaction system and open data, to implement electronic contactless services and to switch to electronic identification and electronic signatures. The e-government should be implemented by the end of 2016. Also one of the tasks of the Cabinet is a complete rejection of the paper document.

On the basis of materials presented above in Table 1 you can see the comparative description of the ICT implementation and use.

\section{Conclusions}

According to the experience of examined countries we can see that the degree of informatisation of the country depends on the direction of government policy. The formation of the legislative foundation for each country was made approximately in one time but the pace of ICT implementation is quite different.

The basic principles of information society in each country are unique in some aspects but at the same time ICT is implemented due to global trends. So global trends can be considered:

- Dissemination of information and communication infrastructure in all areas of human activity

- Establishment of state support by introducing legal regulation and financial delivery.

To the national aspects can include:

- Types of measures for the development and dissemination of ICT (they are formed depending on the level of economic development, mentality, etc.)

Most foreign programs highlight the main characteristicconsideration of all applications of ICT (e-commerce, e-government, etc.) not as independent plans but as a basis for the transition to a fully functioning information society.

After all the essence of the functioning of the information society is not only the automation of economic management and various processes but the improvement the level of world economy and social development through ICT.

Table 1

\section{Comparison of implementation and use of ICT}

\begin{tabular}{|c|c|c|c|c|c|c|}
\hline № & Country & \multirow{2}{*}{ USA } & \multirow{2}{*}{ Canada } & \multirow{2}{*}{ EU } & \multirow{2}{*}{ Japan } & \multirow{2}{*}{ Ukraine } \\
\hline & Implementation & & & & & \\
\hline 1 & $\begin{array}{l}\text { The first year of } \\
\text { ICT regulation }\end{array}$ & $\begin{array}{l}1996 \\
\text { Act about } \\
\text { telecommunications }\end{array}$ & $\begin{array}{l}1993 \\
\text { Telecommunication } \\
\text { Act }\end{array}$ & $\begin{array}{l}1999 \text { The program } \\
\text { "e-Europe" }\end{array}$ & $\begin{array}{l}2001 \\
\text { The program } \\
\text { "e-Japan" }\end{array}$ & $\begin{array}{l}\text { 2003-2004 } \\
\text { The law "About } \\
\text { telecommunications" }\end{array}$ \\
\hline 2 & $\begin{array}{l}\text { The usage of } \\
\text { e-government }\end{array}$ & $\begin{array}{l}\text { Implementation in } \\
\text { 2002-2005 }\end{array}$ & $\begin{array}{l}\text { Implementation in } \\
2001-2005\end{array}$ & $\begin{array}{l}\text { Each country in } \\
\text { EU has its out } \\
\text { time period. Great } \\
\text { Britain (2001-2005) } \\
\text { Germany (2003- } \\
2005) \\
\text { Now the program } \\
\text { "European } \\
\text { e-Government } \\
\text { Action Plan 2011- } \\
2015 \text { " takes part. }\end{array}$ & $\begin{array}{l}\text { Implementation in } \\
2004-2006 p\end{array}$ & $\begin{array}{l}\text { The first phase of } \\
\text { implementation of } \\
\text { e-government will be } \\
\text { in } 2016 \text {. }\end{array}$ \\
\hline 3 & \begin{tabular}{|l} 
Expert evaluation \\
of dissemination \\
of ICT programs \\
(scale from 1 to \\
10 ) \\
\end{tabular} & 9 & 9 & 8 & 10 & 2 \\
\hline 4 & $\begin{array}{l}\text { The percentage } \\
\text { of Internet users } \\
(2014)\end{array}$ & $86.9 \%$ & $94.7 \%$ & $76.5 \%$ & $86.2 \%$ & $41.8 \%$ \\
\hline 5 & $\begin{array}{l}\text { Expenditure on } \\
\text { ICT (percent of } \\
\text { GDP, 2008) }\end{array}$ & $7.36123 \%$ & $6.60479 \%$ & $6.31393 \%$ & $6.68706 \%$ & $5.92647 \%$ \\
\hline
\end{tabular}

\section{References}

Ukraine 2020. Strategy development. Retrieved from http://www.nbuviap.gov.ua/images/4/str.pdf Report «Assessment of electronic readiness of Ukraine» (2013). State Agency for Science, Innovation and Informatisation of Ukraine. 
James Moore (July, 2015). Digital Canada 150. Retrieved from http://www.ic.gc.ca/eic/site/028.nsf/eng/home Information technology Association of Canada. Retrieved from http://itac.ca/

E-Europe Action Plan. Retrieved from http://ec.europa.eu/idabc/en/document/70/5849.html

Jake Enwright (July, 2014). Connecting Canadians. Retrieved from http://news.gc.ca/web/article-en. do?nid $=869539$

Federal Communication Commission. Retrieved from http://www.fcc.gov

Universal Service Program for Schools and Libraries (E-Rate). Retrieved from https://www.fcc.gov/guides/ universal-service-program-schools-and-libraries

Rural Health Care Program. Retrieved from https://www.fcc.gov/encyclopedia/rural-health-care

Lifeline Program for Low-Income Consumers. Retrieved from https://www.fcc.gov/lifeline

Universal Service for High Cost Areas - Connect America Fund. Retrieved from https://www.fcc.gov/ encyclopedia/universal-service-high-cost-areas-connect-america-fund

Nicholas Economides (1998). The Telecommunications Act of 1996 and its Impact. Retrieved from http://www.stern.nyu.edu/networks/telco96.html

National Telecommunication \& Information Administration. Retrieved from http://www.ntia.doc.gov/about

E-Japan: Summary. Retrieved from http://japan.kantei.go.jp/it/network/0122summary.html

E-Europe 2005. Information society for all. Retrieved from http://www.etsi.org/WebSite/document/aboutETSI/ EC_Communications/eEurope2005_actionPlan.pdf

E-Japan Strategy II. Retrieved from http://japan.kantei.go.jp/policy/it/0702senryaku_e.pdf

European Commission Research \& Innovations. What is FP7? Retrieved from https://ec.europa.eu/research/ fp7/understanding/fp7inbrief/what-is_en.html

Japan Strategy in Information and Communication Technology. Retrieved from http://japan.kantei.go.jp/policy/ it/100511_summary.pdf

Digital Agenda in the Europe 2020 strategy. Retrieved from http://ec.europa.eu/digital-agenda/en/digital-agendaeurope-2020-strategy

\section{Марина ШУМАЕВА}

ОСОБЕННОСТИ СТРАТЕГИИ ИНФОРМАТИЗАЦИИ ОБЩЕСТВА В СТРАНАХ МИРА

Аннотация. Актуальность исследования обусловлена глобальной информатизацией и активным формированием открытого информационного общества. Особое внимание уделяется распределению информационно-коммуникационных технологий (ИКТ) между развитыми странами и в обществе в целом. Целью работы является анализ различных стратегий и электронных программ для внедрения ИКТ в разных странах. В работе показано, что каждая страна имеет свой собственный путь развития новых технологий и перехода к новой информационной эпохе. Методика. В статье рассмотрены политики формирования информационного общества в отобранных странах: США, Канады, Европейского Союза, Японии и Украины. Проанализированы стратегии и электронные программы внедрения ИКТ, проведен сравнительный анализ и выделены основные тенденции формирования информационного общества в странах мира. Была воссоздана историческая хронология принятия правовых актов для развития информационного общества. Были рассмотрены различные программы, которые реализуют ИКТ во всех сферах человеческой деятельности. Законодательство является основой всех программ в области ИКТ, которые реализуются в стране. Менее развитые страны должны проанализировать и принять на рассмотрение опыт стран, которые уже успешно используют ИКТ во всех сфера деятельности. Результаты. Согласно исследованию можно утверждать, что степень информатизации страны зависит от вектора направления политического режима правительства страны. Формирование законодательной базы для каждой страны было сделано примерно в одно время, но темпы внедрения ИКТ весьма различны. Все страны следуют глобальным тенденциям и основным принципам формирования информационного общества и в то же время дополняют программы определенными национальными аспектами. Основная цель программ ИКТ это распространение информации и коммуникационной инфраструктуры во все области человеческой деятельности, реализация электронной коммерции, электронного правительства, и т.д. В таблице 1 предоставлена сравнительная характеристика внедрения и использования ИКТ: год начала внедрения ИКТ, год начала использования электронного правительства, экспертная оценки распространения программ в области ИКТ, процентах интернет-пользователей, расходы на ИКТ (в процентах от ВВП). По данным мы можем увидеть, как государственная политика может повлиять на развитие ИКТ в стране. 